\title{
HEIDEGGER'S VIEW AND APPROACH TO SCIENCE AND ITS SIMILARITIES AND DIFFERENCES BEFORE AND AFTER THE "TURN"
}

\section{Marián Ambrozy College of International Business ISM Slovakia in Prě̌ov}

\begin{abstract}
The topic of science was one of the most significant topics in the work of Martin Heidegger. Heidegger was not primarily a science methodologist; he could be considered a significant philosopher of science. Heidegger's philosophy of science is often labeled supertemporal. Although Heidegger was interested in reflecting several stages of science, the present article only deals with his philosophical view of modern science. The article does not analyze how Heidegger reflects on particular sciences; it analyses how he reflects on science as a whole, specifically the individual stages of Heidegger's philosophy of science. The basic question of the research is whether his philosophy of science before the "Turn" is in any way different from his philosophy of science after the "Turn," i.e., whether we can speak of two completely different approaches to science, or whether it is possible to find some continuity between them. Besides Heidegger's published works, the paper also reflects on the discovery of an original, unpublished version of his text and looks critically at some interpreters of Heidegger's philosophy of science. The study concludes that despite numerous differences in his reflection on science before and after the Turn, it can be stated that there is substantial continuity between the stages of Heidegger's philosophy of science.
\end{abstract}

\section{INTRODUCTION}

Heidegger's contribution to the field of philosophy of science is immense. He proved himself to be a significant philosopher of science. After several decades we can see today that his visionary estimate has proved to be exceptionally accurate (Slomski 2017). It can be said that criticism of science prevailed in his work in the period before the Turn. However, this criticism also offered some solutions. Later, Heidegger changed his opinion, claiming that science and philosophy were separate from each other. Philosophy has ended and should be replaced with thinking. In both periods, he remained critical. However, one cannot say that Heidegger was unaware of this difference and did not consider it before the Turn. 
Many philosophers believe that after the Turn, Heidegger started to reject science and that his initial relatively positive attitude changed to rejection. We assume that this assertion cannot be considered accurate.

As Kružíková (2016, 349-350), a Czech researcher, remarks, researchers usually divide Heidegger's philosophy of science into four stages - logical, existential, metaphysical, and epochal. For simplicity, this paper divides Heidegger's work into two periods - the period before and after the Turn. It should be noted that according to Kružíková (2016), understanding science in Heidegger's Being and Time and his texts published earlier is only seemingly different. One common element is the initial viewpoint, which is in line with Husserl's approach that opposes psychologism. Rouse $(1985,75)$ says that in the period following the Turn, Heidegger tried to oppose the recent Anglo-American philosophy of science. Heidegger's earlier interactions with logical positivism, which started at the conference in Davos in 1929, are well-known (Rheinberger 2016). Kružíková further mentions that the third and fourth stages of Heidegger's philosophy of science often merge into one. For the reasons mentioned above, the present article only addresses the first and second stages of Heidegger's reflections on science.

There are considerable differences between the periods before and after the Turn in Heidegger's philosophical work. The primary difference is that, before his Turn, Heidegger's thought was based mainly on the existence of man, the unlocking of Being means the way out of the being of man, and after the Turn, it was based on Being itself and its clearing in the sense of historical epochs. In his thought, after the Turn, its center is transferred from man to Being. From the perspective of Being, there comes a clearing that is independent of man. Heidegger - a countryman, was inspired by nature, clearing as the one in the forest. A clearing means that Being itself arises before man and appears to him; he stands face to face with it, he ek - sists. The Being of truth cannot be inferred from man and his existential structure. The Being of truth is the truth of existential spatiality. Each clearing of Being in the epochal act of metaphysics is also its concealment and refusal. In this sense, Heidegger speaks about the clearing - the concealing advent of Being. Even after the Turn, he insists on a difference between asking about a being and asking about Being. He says that metaphysics asks about the Being of a being. However, Heidegger himself asks about the fundamental nature of Being. It does not mean the question about the purpose of Being (as before the Turn), but a question about how Being reveals itself, and at the same time, how it resists and conceals itself. Heidegger's Turn of thought lies in the fact that - as he himself claims - instead of purpose, truth followed. The purpose of Being is sacrificed in favor of the truth of Being. In Kehre - the Turn, thinking does not convey a being as a being but Being as Being.

The main goal of this article is to ascertain whether the level of Heidegger's reflection of science before and after his Turn was the same or different. In this sense, the following will be carried out: First is a chronological analysis of Heidegger's reflection of science in his main texts germane to the present topic; second is to show the relation between the terms mathematics and science, and their difference before and after the Turn; third is to introduce the difference between the relation among Being, philosophy, and science in both mentioned periods; fourth is the answer to the 
question whether based on the acquired results, Heidegger's philosophy of science before and after the Turn was the same, or what are the differences.

In this study, the term ontology is used in three different ways: traditional ontology, which explored a being as a being; Martin Heidegger's fundamental ontology; ontology of science as the exploration of the nature of science.

\section{HEIDEGGER'S UNDERSTANDING OF SCIENCE BEFORE AND AFTER THE TURN}

\section{Perception of science before the Turn}

Heidegger's early period in the 1920 s is characterized by his philosophical interest in depicting thematization, which considers both science and philosophy and attempts to explain what is called "factual life" (Johnson 2012, 122). In this period, Heidegger was still directly inspired by Husserl. "Early Heidegger introduces the program of philosophy as the science of all sciences, and he is able to connect it with his teacher Husserl and philosophical tradition" (Wolf 2003, 96). However, even early Heidegger did not always agree with Husserl, despite all his influence. Heidegger criticized Husserl's intentionality. In Mabaquiao's opinion, his criticism rested mainly on his rejection of Cartesian dualism. (Mabaquiao 2009, 100). Heidegger tried to formulate a logical structure of the theory of science in his early works, namely in his lecture The Concept of Time in the Science of History (Zeitbegriff in der Geschichtswissenschaft) (1915). In this lecture, he speaks of a strong metaphysical desire in science, whereas the search for a logical picture of sciences should lead to the postulation of scientific categories. He also emphasizes the importance of differentiating between natural and historical sciences with respect to time. As to the manifestation of time in the natural sciences, Heidegger identifies with the key standpoint of Galileo Galilei [1564-1642], for whom the basic term is position as a manifestation of motion, a way of expressing motion in time as introduced by Galileo himself. With this way of characterizing time, it is possible to characterize modern physics as a mathematically expressible invariant of motion. This is a completely new understanding of science. It attempts to gain control of the diversity of phenomena by means of law, and the way it attains to the law is its own new accomplishment (Heidegger 2008, 18). In this case, the aim of physics is to transfer phenomena to the laws of substance motion. In a Cartesian system, time moments differ by their placement. Values $\mathrm{x}, \mathrm{y}$, and $\mathrm{z}$ in a three-dimensional space "depend on the relevant value of $t$, i.e., they are functions of time $[x=x(t), y=y(t), z=z(t)]$. If the value of time $t$ changes by an indefinitely small value, the values of the co-ordinates will change as well" (Kružíková 2010, 22). Naturally, in modern classical physics, the assumed change of time lies in a change of the time continuum. "This function of time in physics as presented by Heidegger leads to the assertion that time as an independent variable has a homogeneous, quantitative and mathematical character in physics" (Kružíková $2014,35)$. With respect to his works at that time, De Lara $(2014,73)$ criticizes Heidegger for his philosophical esoterism and elitism, claiming that the said 
standpoints are not generally accepted and are not compatible with the presentation of philosophy as a discipline accessible to those who are involved in it.

In Being and Time (Sein und Zeit) (1926), the period before the Turn was not reflected only in the topics of metaphysics, the analysis of temporality, and the ontology of there-being as being to death (Vaňková 2017). The said work has many dimensions. Köchler $(2011,41)$ writes, "As Martin Heidegger has aptly explained in Sein und Zeit, the question as to the real (actual) existence of the 'outside world' makes no sense, because the conditio humana is tantamount to, and can only be understood as In-der-welt-sein (being-in-the-world." Being and Time does not avoid the topic of science either. Heidegger tries to express the difference between philosophical and scientific approaches to knowledge. He assumes that the topic of ontology is, from the historical point of view, of primary importance. In his opinion, scientific research is clearly marked by boundaries. He believes that if an experiment proves a scientific theory, it can be considered true (Mascaró 2017, 179). Research works with basic terms, which are connected with the founding of a concrete scientific discipline. For Heidegger $(2010,8)$, "its true progress comes about not so much in collecting results and storing them in 'handbooks' as in being forced to ask questions about the basic constitution of each area, these questions being chiefly a reaction to increasing knowledge in each area." Science is considered developed when it is capable of selfreflection without any interference from other areas. Heidegger considers the crisis of asking questions of the positive sciences as a crisis of the foundations of sciences as such. He thinks that the question of basic terms of special sciences deserves more attention than the particular problems of these sciences. He supports the above opinion with the argument that the questions of ontology are older. In his opinion, the topic of the basic concepts of areas of knowledge is more important than the research of positive sciences.

It is worth noticing that even before the Turn, Heidegger clearly differentiates between the role of sciences and the field of study of ontology. However, he never says they are incompatible. With respect to the sciences, he states that they are "involved in an understanding of Being" (Heidegger, 2010, 4). For Heidegger, the scientific grasping of a being is one of many possible ways of grasping it. Shortly before the Turn, Heidegger addressed science in his work Phenomenological Interpretation of Kant's Critique of Pure Reason (1927/28). He (1997, 13) aimed to determine the existence of science on the basis of the existence of Dasein. Both the scientific and pre-scientific disclosure of concealed being have common features; however, the scientific approach rests in the fact that a Dasein which exists assigns itself the task to reveal a being that is already present in order to be revealed (Heidegger 1997, 18).

The task is to free and reveal a being, which is carried out by means of materialization. A being exists before it is materialized. "Human Dasein in a capitalist society identifies its very self by its labour" (Pomeroy 2008, 135). It gradually becomes an object, thus providing answers to questions asked with the aim of understanding a being in a broader context. For science, a being is basically an object to be revealed. Science needs to understand its basic structure and examine it. With respect to the aforementioned claims, Heidegger repeatedly emphasizes the importance of understanding the basic concepts of the relevant sciences. In his opinion, it is crucial to define what can be the object of study of a particular science. In the above treatise, 
he speaks of the competencies of a science that addresses its research topics. On the other hand, however, he $(1997,26)$ claims that "with respect to the basic concepts of their sciences, the methods of this science fail." The founding of sciences exceeds the methods and competencies of sciences. Heidegger speaks of regional ontology, i.e., the object of each science must be outlined in accordance with the regional structure of Being. "In Heidegger's opinion, sciences are closely connected with ontology as scientific philosophy, even though they might not be aware of it, as they may be so highly developed and specialized" (Kuneš 2011, 225). Historically, science has its roots in philosophy. Since science should not define its basic concepts, then "all science is potentially and in principle philosophy" (Heidegger 1997, 26). Shortly before the Turn, Heidegger reached a conclusion that despite the above-mentioned, scientific research independent of philosophy is possible.

Martin Heidegger addressed the topic in Phenomenology and Theology (1927). In his opinion, there are no major differences among the positive sciences. In Heidegger's opinion, positive sciences, which also include theology, materialize their topics and further develop the existing pre-scientific approach to a being (Heidegger, 1998a, 45). This brings positive sciences even closer to each other; for example, theology is closer to chemistry and physics than to philosophy. The sciences tropicalized their fields. A being has been revealed by the pre-scientific approach and becomes the topic of materialization. In his lecture, Heidegger deals with the topic of science only marginally and on the same level of reflection as in his other works devoted to Kant, written in the period shortly before the Turn. As Paić (2014, 198) says, Heidegger, in the said lecture, addressed the dispute between faith and reason. Lewis $(2017,70)$ reminds us that in his lecture, Fundamental Concept of Metaphysics (1929/1930), Heidegger speaks of the possibility of reconciling philosophy and science, an effort in which saints and poets can also take an active part. Heidegger was also influenced by Kierkegaard's and Kant's concepts of the philosophy of values (Garcia - Martin et al. 2021).

As already mentioned, Heidegger's work Being and Time also includes the topic of science and its significance. In his next well-known lecture, What Is Metaphysics? (1929), Heidegger's opinion on the above topic remains the same. There is no hierarchy or superiority among scientific disciplines. Informatics is not more of a science than, for example, jurisprudence. The sciences have their specific manners for how to grasp being. They each have their own object of research. "In all the sciences, when we follow their own most proper aim, we relate ourselves to be-ing itself" (Heidegger 1998b, 83). It is up to the being itself if it appears. Humans invade a being by force with the help of science. Under such circumstances, a being can appear. Nota bene: there is a second version of the lecture. In 2017 an authentic, previously unknown typescript was discovered. It also changes Heidegger's approach to science. "Rather than trying to ground the sciences, the original sets itself in stark opposition to them" (Moore 2019, 531). Scientific inquiry touches upon the entirety of Being; the result, however, is merely a manifestation of its certain part. In the original, unpublished version of the lecture, Heidegger intensifies his criticism. He says that if science does not take anything seriously, its superiority becomes absolutely laughable. Compared to the published version, he perceives the contrast between science and 
metaphysics as even sharper. In the original version, Heidegger says that understanding among sciences is absurd, which is dangerous for the sciences since it is very difficult to work without understanding (Moore 2019, 544). Moore claims that the published version is more tactful towards science and the original version is closer to Heidegger's views after the Turn.

The radical change in Heidegger's approach started in approximately 1930 (Corti 2006, 17). Even after that year, the topic of reflexive science remained one of the most dominant topics of his philosophical work. Heidegger's last philosophical text, which he wrote two weeks before his death, is devoted to science (Ma and van Brakel 2014, 19-20). The topic of that study is not to analyze the Turn. Heidegger only wanted to look at it with respect to a reflection of science. In this context, one can ask: to what extent did Heidegger change his approach to science compared to the period before the Turn? It will be interesting to find out if Heidegger negates science or if he asks the question anew. Is he going to approach the problem from new standpoints?

In 1931, at the time of the Turn, Heidegger presented a series of lectures devoted to the analysis of the concept of power in the ontological context in Aristoteles' Metaphysics. In the said lectures, he comments on the audacious attempt to grasp reality and create valuable works of spirit as follows: "The academic proletariat prevails, however, in a completely different way. One must say without exaggeration: A scientific 'peak performance' today - to use that dreadful expression - has long had no need for the aristocracy of the spirit. Those who have long since been provided for are also precisely those who have long since been proletarians because they feel complacent in their impotence toward aristocracy" (Heidegger 1995, 69). His critical view of science thus unequivocally dominates his work already at the beginning of the Turn.

After the Turn, Heidegger becomes more critical of science. The question is to what extent he just continued with the topic of reflection of science or to what extent his approach changed compared to the previous period.

\section{Perception of science after the "Turn"}

Now imagine Heidegger's relation to science in the period after the "Turn." Here, Heidegger mentioned this topic in several of his main works. Scale-wise, it is a larger database of works that mention the topic of science than in the period before the Turn. This subchapter will discuss Heidegger's approach to science after the Turn.

His visionary text The Age of the World Picture (1938), written shortly after the Turn, is an even more significant reflection of science. Here he speaks of dedivinization, which was an important term for science. By de-divinization, Heidegger (1977b, 117) means "the situation of indecision regarding God and the gods."

In the above-mentioned lecture, Heidegger says that a being becomes an object in science. If this happens, a being is basically torn out of context and loses something after its objectification. Research might seem very violent in such a case. The research plan "sketches out in advance the manner in which the knowing procedure must bind itself and adhere to the sphere opened up" (Heidegger 1977b, 118). If we objectify facts, the aspect of movement disappears. Change is expressed as invariance, law, and rule. Science is thus a connection of invariance and rigidity. 
According to Heidegger, "mathematical projection of nature serves as a basis for modern natural science and, since the times of Descartes, also for modern philosophy" (Tholt 2003, 86). From an etymological point of view, the origins of mathematics can be searched for in $\tau \alpha \mu \alpha \theta \eta \mu \alpha \tau \alpha$, which means entities that can be learned in advance. Heidegger (1977b, 120) defines mathematical natural science as follows: "the self-contained system of motion of units of mass related spatiotemporally." The movement of points in time and space can be quantified.

Heidegger emphasizes that current science offers no surprises. There is too much planning in science, and science management is too rigid. This way, we might lose unexpected Turns in scientific research. A researcher who is managed according to a plan and who has to consider the economic aspect replaces a scholar who can work on the basis of his/her knowledge database. Planning is based on economic interests, and they can have a significant influence on publishing houses and their selection of publications.

Chinese researcher $\mathrm{Ke}$ (2016) points out the term "Besinnung," which Heidegger uses in Contributions to Philosophy. He uses it for naming the ontological grounding effort of reason which should substitute a rational critique of the sciences (Ke 2016).

Progress in physics can be documented by the technologies used in experimental physics. "Within the complex of machinery that is necessary to physics in order to carry out the smashing of the atom lies hidden the whole of physics up to now" (Heidegger 1977b, 124). Machines verify the results. Not every science has the same exactness because it depends on the way individual sciences verify their results. Each science studies different objects. Sometimes science can explain something known by means of something which is not known. Causality is a typical feature of modern science. Turning knowledge into research is proof that experiments dominate modern science. Science attempts to identify invariants through research. Results of experiments either verify an invariant or not. In modern empirical science experiment plays an important role. Its purpose is to be a decisive indicator of a theoretical prediction. Heidegger postulates a proposal regarding the division of sciences. In his lecture What is a Thing? (Die Frage nach dem Ding) (1935/36) he differentiates between mathematical and empirical sciences. The term mathematical does not mean that the basis of these sciences is mathematics but that "the research of fields and topics is carried out methodically" (Kružíková 2010, p. 75). Research is planned, and it works with a being that is known beforehand. How individual sciences proceed depends on their objects of study. In his work An Introduction to Metaphysics (1935), Heidegger spoke of an encounter of global technology and modern humanity, which is an early perception of the concept of Gestell, i.e., the essence of technology (Heidegger 1959).

Science and Reflection is another of Heidegger's lectures that is important for our analysis. In it, Heidegger initially analyses the topic of Ge-stell in science. He also tries to provide an etymological analysis of the words real and theory. He builds his analysis on the common Indo-European origin of the German and Greek languages. He claims that the German word das Wirkliche depends etymologically on Esyov. He (1977c, 160) explains it as something "which in the genuine and highest sense presences." He derives the origin of the word theory from $\theta \varepsilon \alpha$ and o $\varsigma \alpha v$, i.e., to watch, 
observe, look at. He suggests translating the term $\theta$ copıó as Betrachtung, which means to capture or entrap the real. Heidegger understands science as the theory of the real. In science today, acquiring what exists in the form of an object is preferred.

Heidegger also analyses science in the postscript to his famous lecture What Is Metaphysics? (1943). He does not consider modern science purposive. On the other hand, he claims that modern science does not search for the truth. He (1998|) describes it as a means of calculating the reification of Being. Objectification in science takes place by means of entrapping a being. Regarding the exactness of science, Heidegger believes that this is actually a limitation because science is dominated by calculation. In his opinion, quantitative thinking is sterile, as it only consumes numbers. He literally says that calculation devours. Science brings a being to people in a digestible form. "Heidegger refers to calculating, i.e. application of ordering rules to identified beings as consuming use of being (der verbreuchende Gebrauch des Seienden)" (Nitsche $2005,225)$. The unity of a being is beyond calculation. A being cannot capture the truthfulness of Being by means of calculation. This dimension cannot be calculated because the pragmatic viewpoint plays no important role here. In his Letter on Humanism (Brief über den Humanismus), the philosopher from Messkirch says that ever since the times of Plato and Aristoteles, thinking has been understood as $\tau \varepsilon \dot{\varepsilon} \chi \eta \eta$. Since then, thinking must justify its existence when confronted with sciences,

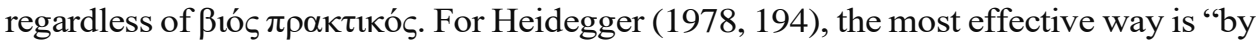
elevating itself to the rank of a science." Philosophy is afraid that it will be excluded from among the sciences and considered unscientific, and as a result, it abandons thinking and sacrifices Being.

In his significant work What is Called Thinking? (Was heist Denken?) (1951/52) Heidegger claims that science does not think. He believes that there is a gap between science and thinking which makes contact between science and thinking very difficult. He $(1976,14)$ further states that all donkey bridges between thinking and science built with the aim of developing barter between the two are useless. Philosophy dissolves in scientific thinking, and the thinking which replaces it has nothing to do with science. Heidegger is convinced that metaphysical philosophy has come to its end. It will be replaced by thinking which is totally different from science. Progress cannot help scientific philosophy attain thinking. Its aim is a technical world that originates by interconnecting psychoanalysis, psychology, and sociology.

Science tries to postulate the picture of the world. This is what unifies theoretical science and experimental science. "Thus, the modern scientific inquiry disregards what is essential in the authentic knowledge of a thing, that is, the manner in which it presences or becomes knowable. In fact, as Heidegger argued, for the Greeks, the meaning of theory is determined not by what can be measured, as claimed, for instance by Max Plank, but as a form of looking attentively upon the aspect of what appears to us" (Bagni 2010, 77). An object itself cannot answer the question to what extent nature hides its essence, as Heraclites says. Heidegger explains his understanding of the term Gestell in his work The Question Concerning Technology (1955). Etymologically the word comes from the verb stellen. For Heidegger (1977a, 20), "Enframing means the gathering together of that setting-upon which sets upon man, i.e., challenges him forth, to reveal the real, in the mode of ordering, as standing reserve." Physics as science uses various traps for a being to show that it can be calculated in terms of the structure of 
objects in quantified relations. Theoretical science tries to provide a picture of nature that is quantifiable. The purpose of uncovering the essence of nature is to acquire energy from nature. Heidegger emphasizes that Gestell means to focus on the objectification of nature, which makes uncovering other forms of a being impossible. In his opinion, this is dangerous because humans start treating nature as predators. Thus, the objectification of nature "disappears into objectlessness of standing-reserve" (Heidegger, 1977a, 9), and humans can in this way reduce a being. This is one of the reasons why Heidegger despises the enlightened idea of progress in both positivist and Marxist forms (Nemec 2018, 61). Both communism and admiration of developing technologies relate, although in different ways, to enlightened ideas of progress (Sousedík 2005, 197).

Heidegger also analyses the relation between science and philosophy in his treatise The End of Philosophy and the Task of Thinking (Das Ende der Philosophie und die Aufgabe des Denkens) (1964), in which he points out that sciences were already created within metaphysics in the ancient world. "Heidegger considers that Philosophy be ended in order to realize the task of scientificity itself which does not pertain to modern Science, nor to Philosophy" (Mitterpach and Štúr 2017, 158). The creation of sciences is a departure from philosophy. Science unlocks various areas of a being. Philosophy loses its original form of metaphysics. "Philosophy Turns into the empirical science of man, of all of what can become the experiential object of his technology for man, the technology by which he establishes himself in the world by working on it in the manifold modes of making and shaping" (Heidegger 1972, 57). In the near future, the world of science will be determined by cybernetics. "Philosophy as 'metaphysics' has split into a number of special sciences and now faces two options - to become 'cybernetics' or 'poetry' (whereas it naturally often chooses the first option influenced by the example of the scientific method)" (Beran 2010, 336). Philosophy dissolves in sciences. The approach of sciences to the original topics of philosophy is very technical.

Heidegger is, in many aspects, a timeless philosopher. He asks questions that have not been answered yet. One can observe occasional visionary aspects in his texts. $\mathrm{He}$ (1971) asks questions regarding the essence of technology and the preparation of a free relation to technology. Heidegger explains his famous statement "science does not think" in an interview given on the occasion of his 80th birthday. Naturally, his interpretation is not trying to dishonor science. He only points out the fact that the approach and means of science do not enable science to think. Thinking which follows philosophy is not compatible with science. Philosophy is not thinking. In the said interview, Heidegger repeats what he has said so many times before. What we call philosophy today is just a copy of technical ideologies using the methods of physics and biology. We can no longer speak of asking authentic philosophical questions (Heidegger 1971). As he critically says, science Turned out to be mere objectivity, and technology is just the perception of the world as a standing reserve (Heidegger 1971). He asserts that science is power-hungry, and the fact that it does not think means that science does not operate within the dimensions of philosophy even though it has to rely on them. He demonstrates this in the example of physics, which operates within a certain time and space. Nevertheless, science is not competent in providing definitions 
of time and space. On the one hand, science has to rely on what philosophy thinks, while on the other hand, it forgets Being. Heidegger tries to prepare thinking, anticipating future thinkers who would be able to take over thinking in philosophy which, in his opinion, has come to its end.

Caputo is very critical of Heidegger's criticism of science after the Turn. In his opinion, Heidegger presents two "essences" of science, whereas the first was suppressed by the second. Caputo $(1986,44)$ identifies the first one in Being and Time and calls it the "hermeneutic" essence of science. "The second essence of science and technology is its Wesen in the later, more radical sense - let us call it here its 'deconstructive' sense - which signifies an entire understanding of man and world, of being and truth, which Heidegger wants to delimit, to critique, to disrupt." Despite the differences, Caputo $(1986,55)$ tries "to show that there is a fruitful interplay, and not an antagonism, between the two essences of science." He believes that Heidegger's animosity towards science is just a misunderstanding on the part of the interpreters. Nevertheless, Caputo's opinion on Heidegger's criticism of science after the Turn remains very critical.

Pandiaraj attempts to defend Heidegger's approach to science after the Turn. For him $(2019,389)$, "Heidegger wanted to disrupt and demystify the total authority of the modern scientific narrative and suggest alternative ways of understanding human essence and the human relation to nature." According to Pandiaraj, Heidegger, by shifting the historical context, simply reacts to science in a way helping him achieve further goals which he did not aim at before the Turn. "Heidegger's early hermeneutic account of science, which delineates knowing the world - including scientific knowing - as a mode of being founded upon being-inthe-world, would have fulfilled the task of his later deconstructive account of modern science without prejudice towards scientific knowing, does not take cognizance of his post-metaphysical aim of pluralizing the ontological discourses and stimulating alternative ontological futures and possibilities in the technoscientific Anthropocene epoch" (Pandiaraj 2019, p. 402). science must also be aware of the important role of art and poetry. Visual arts, for example, are very specific. As Sucharek $(2013,738)$ says, "the purpose of looking at a picture should not be just running one's eye over the surface of things."

Heidegger's attitude was never purely anti-scientific. We dare say that in the whole of Heidegger's work, regardless of its stages and despite considerable differences in his standpoints, there are many similarities in his reflections of science which show some continuity. He was the first to speak about the superiority of technology over science. Until the 1980s, nobody was able "to grasp what it was that Heidegger was shouting out and about" (Forman 2007, 9). Heidegger's reflection of science, including his critical remarks, is supratemporal and up-to-date. "It is legitimate to ask questions concerning the applicability of ethical criteria on original scientific research and its subsequent implementation in the world of new technologies and innovations" (Valčo 2018, 1). The problem is also related to the crisis of values, says Králik (Králik 2019, 1-2). Despite critics who claim that science has changed since Heidegger's death, rational researchers of the field of science reflection simply cannot ignore Heidegger's ideas. "Theorists concerned about the nature of science did not seize upon Heidegger's work" (Shaw 2012, 9). 


\section{RELATIONS BETWEEN HEIDEGGER'S PHILOSOPHY OF SCIENCE AND PHILOSOPHY OF MATHEMATICS}

Even before the Turn, Heidegger had established that the goal of modern physics is the reduction of phenomena into mathematically expressible laws of motion. The mathematical nature of science is also closely related to the mathematical scheme of science which is based on the materialization of the objects of nature. Nature itself is reduced to a set of facts despite its mathematical character. Heidegger had thus already expressed his opinion regarding mathematization in science prior to the Turn. He (2008) said that in accordance with its modern founding, natural science must be defined in a way that enables its mathematical definition. The essence of the mathematical structure of nature is its comprehensibility. According to Heidegger, the mathematization of natural science is its materialization, which constitutes scientific knowledge. Science acquires its foundations by materialization. "The process of objectivization and mathematization of the world results in a subject's claims to gain control of and rule nature, precisely measure and calculate the world as a group of observable objects" (Tomašovičová 2002, 337).

In the period after the Turn, Heidegger brings to attention the etymological meaning of $\tau \alpha \dot{\alpha} \mu \alpha \theta \varepsilon \dot{\varepsilon} \mu \alpha \tau \alpha$, as that which is possible to learn. Similarly, he points out that it is what we know beforehand. Place, point, and force are seen as interchangeable. Here is where the pre-experiential approach of the mathematical nature of science lies. In the narrower sense of the word, mathematical sciences predict their results through calculations. All empirical sciences are considered mathematical in a wider sense of the word because they bring a being directly into experience, into subordinated control (Kružíková 2010, p. 74). After all, mathematical calculability is also connected to the reduction of nature into the state of supply.

For Heidegger (1977a, 274), the key term here is the mathematical, or " $\tau \alpha$ $\mu \alpha \theta \varepsilon \dot{\varepsilon} \mu \tau \alpha$, what can be learned and thus, at the same time, what can be taught." Heidegger's answer to the question of what mathematics is is not derived from mathematics. Heidegger assumes that the word mathematical as an adjective cannot be assessed only from the viewpoint of mathematics as a science. "Motiv $\mu \alpha \theta \varepsilon \dot{\mu} \mu \alpha$ is related to preliminary understanding, to pre-understanding with which we always approach things as something which is specifically related to us as human beings" (Novák 2010, 22). He refuses to associate the mathematical with numbers only. He believes that $\mu \alpha \theta \varepsilon \varepsilon \mu \alpha \tau \alpha$ are things we already know. We try to take note of something which we already know. We do not get the mathematical from things around us; we bring it along. We know three as a number, and the empirical state of things cannot teach us anything more. We do not learn about triality from things.

Heidegger claims that the mathematical is what pre-defines things. Basically, it is awareness of the basic pre-condition for all knowledge. It is awareness of the fact that there are certain pre-conditions for genuine knowledge inherent to human beings. This is how Heidegger tried to come to terms with Plato and especially with Kant. "Kant could define metaphysics as science only after he found out how pure mathematics and pure natural science are possible as sciences" (Leško 2006, 348). 
The attempt to understand the mathematical is connected with the understanding of things.

In Heidegger's opinion, mathematics is not a natural science, as it does not care about the state of things. Knowledge itself assumes that there is a certain preknowledge, which is again a reference to Plato's work, whose endeavor is a conception of the absolute that does not leave out multiplicity or oneness, being or non-being, identity or difference, motion or rest, but incorporates all of them analogously into the eidetic foundation of the real" (Binnetti, Králik, Tkáčová, Roubalová, 2020, 8). Heidegger believes that the mathematical served as a basis for modern mathematics as well as modern metaphysics and modern natural science. Interestingly, the mathematical is based on a certain number of basic propositions axioms. Heidegger calls the axiomatic system of the working of knowledge mathematical. For him, axioms are not only fundamentally indemonstrable preconditions for a mathematical system. He $(2008,291)$ claims that "the axioms are fundamental propositions." The mathematical is thus a plan that shows what things are taken for and also the way of approaching these things. In natural sciences, this also includes the approach to numerical measurement. This means that a precondition for mathematical natural sciences is the inner "mathematical" arrangement of nature, i.e., simply said fully quantitative relations" (Belousov 2014, 121).

In his typical way, Heidegger associates the mathematical and related axioms as a fundamental standpoint in science with determining the essence of things. However, the definition mentioned above is no longer a description of a science historian but a direct proposition of Heidegger's, with Heidegger playing the role of a philosopher of the history of philosophy. "Rational reconstruction of scientific progress was the most discussed topic in philosophy in the 1960s" (Karaba 2012, 519). Heidegger had grasped the topic earlier. "Heidegger's interpretation of mathematics might comply with Galileo's understanding of mathematics" (Kvasz 2013, 242). Heidegger's interpretation is, thus on the one hand, a fitting description of Descartes's role in the forming of modern natural science and, on the other, a self-willed interpretation of the mathematical. Heidegger's philosophy of mathematics is specific and transcends both traditional and modern definitions of science. "Heidegger focused on explaining ontological pre-conception which played a decisive role during the scientific revolution" (Kvasz 2006, 203).

The relation among the terms mathematics, the mathematical, and science is significant. Heidegger does not speak about mathematics as a science; he means that science as such is mathematical. He terms it mathematical because, in it, things are given prior to experience, as calculable in advance. Mathematical science has its boundaries in the form of beforehand calculated states determined by the relational possibility of points in time and space. This is closely related to Heidegger's critique of a certain impossibility of surprise in science. It should be stated that Heidegger's approach to foresight in science is linked to the opinions on the philosophy of science of Niels Bohr (Grygar 2021).

Heidegger also postulated opinions that could be considered as a specific philosophy of mathematics; however, those are not stated here, as they are not relevant to the topic of this paper. 


\section{THE EVOLUTION OF THE RELATION BETWEEN SCIENCE AND PHILOSOPHY IN HEIDEGGER'S THINKING}

The problem of the relation between science and philosophy in Heidegger before the Turn is well known. Heidegger reminds of the forgetting of Being. Whereas ontology explored a being as a being, the role of metaphysics is to ask about the purpose of Being, to ask about why there is something rather than nothing. He regarded the purpose of Being as possible. Here, Heidegger does not yet entirely refuse metaphysics as such; he even likens it to philosophy and puts it in contrast to science which surrendered its exploration of Being and focused itself on a being, isolating itself from philosophy - ibid. (Stojka 2015, p. 43). Since the time of Aristotle, philosophy had been focused on ontology, but according to Heidegger, it had forgotten about metaphysics. While traditional ontology is preoccupied with a being, similar to science, it forgets about Being. Heidegger speaks of forsaking a being by Being. Being itself has become the sole domain of metaphysics; the approach of science is completely different. Before the Turn, ontology is possible as phenomenology, which seeks the purpose of Being. It is the reversal of traditional ontology and laying of the foundations of fundamental ontology, which is meant to ask about Being, not a being. Science is thus closer to traditional ontology because it does not deal with Being; it is inherently different from fundamental ontology or metaphysics.

After the Turn, the knowledge of Being is no longer the concern of man, but it depends on whether Being reveals or conceals itself. Philosophy (metaphysics) is to be replaced by thinking after the Turn. Philosophy is no longer capable of approaching the true nature of Being. Thinking itself experiences the existential determination of there-being from its relation to the truth of Being; its questioning is more fundamental than metaphysics. Thinking thus leaves the ground of metaphysics. Heidegger attempts to think of Being from Being, meaning from the history of Being (seingeschichtlich). The end of the history of metaphysics in the second period means the advent of thinking. The materialized thinking is to be replaced by thinking Being will own that, that will listen to Being. It is obviously possible to distinguish between the period when Heidegger interpreted scientific thinking on the basis of the history of there-being and when he saw philosophy to be the alternative to science, from the period when he interpreted scientific thinking based on the history of Being (Seyn) and when he saw a thought or a poem as an alternative to science. (Kružíková 2010, p. 48). The late Heidegger also knew that the purpose of Being is time. Heidegger differentiates between Besinnung a Betrachtung. Besinnung is thinking that allows us to enter the purpose of Being. Betrachtung is calculative thinking. A being thus becomes a source of energy. Metaphysics and philosophy have ended, and Heidegger announces a new beginning - the beginning of thinking.

\section{SIMILARITIES AND DIFFERENCES}

The situation with respect to the reflection of science in Heidegger's two main periods can be compared. Heidegger articulated the stark differences between 
philosophy and science even in the period before the "Turn." Then, he had perceived ontology (in its traditional sense) as historically primary in relation to science. It explores a being as a being. Metaphysics, which asks about the purpose of Being, is even more fundamental. Metaphysics makes up the counterpart to science that does not ask about the totality of a being but materialize it. The scientific manner of grasping a being is thus inherently partial. In a traditional sense of the word, Ontology is not a counterpart of science; metaphysics is. The object of research in science is determined by materialization. Heidegger criticizes the hostile incursion of man into a being.

In his early period in Freiburg, Heidegger perceived phenomenology as the original science of life (Badger 2017, p. 28). In Being and Time, he looked at the role of philosophy through the prism of metaphysics, which is competent to ask questions regarding the purpose of Being. To understand the fundamental question, one needs to understand the difference between Being and a being. This difference is of an ontological nature. "To ask a question regarding being means to try to think the implicit, topicalize it, talk about something we have not said anything about yet, something we could be silent about" (Novosád 1995, 23).

His criticism of sciences in his essays is also traceable prior to the Turn. In his lecture What Is Metaphysics? Heidegger reminds us that "the sciences have lost their rootedness in their essential ground" (Heidegger 1998b, 83). He states that science deals with nothing as something which it believes does not exist. On the other hand, however, science invites nothing to help verbalize its own essence. Similarly, in his lecture Modern Science, Metaphysics and Mathematics, he asserts that the mathematical nature of science leads to diversion from revelation and tradition as components that provide knowledge. Heidegger associates this with negative connotations. It has been found out that Heidegger had written the unpublished version of the mentioned lecture. There, he claims that the contrast between science and metaphysics is very significant; he considers understanding in science as weak as science works without understanding, which he viewed as dangerous. Heidegger pondered the phenomenon of the crisis of sciences and was aware of the differences between philosophy and science. Both metaphysics and mathematics come from the mathematical; nevertheless, positive sciences differ from philosophy. For example, theology, similar to physics, has its scope, which actually is a revealed existence as a potential topic of scientific objectification and research (Heidegger 1998). Sciences reveal relevant segments of a being, while philosophy studies Being. Despite the difference, in the period prior to the Turn, Heidegger perceives the relation between science and philosophy as positive and meaningful with potential for partnership. The above assertion is based on his belief that philosophical knowledge can be relevant and productive for positive science. Science is just the only inexhaustible way of Being. Heidegger was aware of the crisis of the basic concepts of sciences as well as of their principal inability to answer ontological questions already before the Turn. Positive research cannot see the foundations. For instance, the ontological structure "in-derWelt-sein" cannot become an object of scientific study of any positive science.

It could be claimed that in the period after the Turn, his level of criticism towards science had risen. Of course, Heidegger's attitude towards science was also critical in the first period; however, the measure of discrepancy between science and that which should complementarily supplement the limitations in science had increased. 
Heidegger maintained his position of science's materialization of a being. He did not view the specialization of science in a negative way, but he criticized its operational character. His negative attitude was towards the replacement of a researcher with a scholar, on economically determining the planning of science and publications, which he saw as dangerous. He had also introduced the term Gestell in science. He claimed that science pursued nature, placed traps in from of it. He criticizes science for its calculating attitude towards a being, quantitative thinking. Science utilizes numbers. A calculated being will not encompass the truth of Being; science can destroy the Being of things. Heidegger speaks about the abyss between science and thought as a substitute for metaphysics and philosophy. According to late Heidegger, philosophy does not result in thinking but in logistics. He views negatively the preylike relationship of man towards nature which is reduced to the state of resources. Science, in its most fundamental sense of the word, does not think. Thinking is incompatible with science. Identical signs remain in maintaining a critical approach to science. Before the Turn, Heidegger perceived scientific thinking merely as a particular of metaphysical thinking.

Batovanja $(2009,409)$ assumes that despite Heidegger's analysis of different stages of science evolution, their periodization does not play any significant role in his approach to science. Heidegger specifies the individual stages of science evolution; nevertheless, these are not necessary for understanding his way of approaching science and philosophy.

His evaluation of science changed simultaneously with his changing view of philosophy. "Heidegger has already provided a more or less explicit answer to the question regarding the relationship of modern natural science to modern technology" (Ma and van Brakel 2014, 40). Philosophy as metaphysics dissolves in sciences, and the abyss between philosophy and science is a dead-end in knowledge. Philosophy is compared to science and becomes scientific, which is a symptom of its end. Space should be given to thinking, which has to replace philosophy. Science does not think. This does not mean, however, that science does not approach its own working methods rationally. It is just essentially different from thinking, which is supposed to follow the end of metaphysical philosophy. Prior to the Turn, philosophy could address sciences as a discipline that addressed topics it had no competence for. After the Turn, the dialogue between science and thinking ended. For thinking, it was no longer possible to help search for fundamental concepts of other sciences, as it was prior to the Turn.

This is not a manifestation of Heidegger's anti-scientific stance. For example, "Heidegger later investigates how scientific research as an institution works; he claims that research is based on what he calls the projection of a total ground-plan" (Dreyfus 2018, 224). This is just a statement regarding the incompatibility of thinking and science. Heidegger's belief that the view of science is a one-sided view was not an attempt to disparage science. "Even though there are few signs of Heidegger's extremely radical attitude to sciences, we cannot attach more importance to them than they truly have." (Zaborowski, 2014, 52) The view of the relation between science and philosophy changed, and the criticism of science increased. Heidegger, however, never adopted a standpoint denouncing sciences. The fact that Heidegger did not denounce 
science was only one sign of the continuity of the period preceding the Turn. Other signs of the said continuity were his awareness of the essential difference between science and philosophy as well as the continuing and intensifying criticism, which, however, never became destructive. The extent of his criticism changed; nevertheless, he never accepted the role of judge, and despite introducing new aspects of criticism, Heidegger never denounced or ostracised science. He never said that there was any hostility between science and philosophy.

A focus on the precisely defined competencies of philosophy (or thinking) and science can be observed in both stages of Heidegger's scientific work. In his opinion, differences among sciences are not of primary importance. He kept his belief that science cannot reflect its own essence throughout his whole professional life. He never contradicted his belief that science in its entirety is not able to encompass the potentially possible diapason of knowing. According to Heidegger, the belief that science plays an exclusive role in knowing is incorrect.

A significant characteristic of Heidegger's reflection of science also perceives its mathematical nature. This moment is present in Heidegger's thought both before and after the Turn. He saw the mathematization of science as proof that science is teachable and understandable in advance, enabling materialization. Heidegger regards the mathematical nature of science as reflecting that things are known in advance, are, in their own way, given beforehand. The mathematical nature of science is the most fundamental aspect of the approach to thinking in modern times. It is also connected to the restriction of the element of surprise in science.

Regarding the relation between science and philosophy in both periods of Heidegger's thought, we can see that his attitude is radically different in the period before and after the Turn. Before the Turn, philosophy is seen as diametrically different from science in its approach. Science itself is close to traditional ontology, which explored a being as a being, but it forgets about Being, about its purpose. As opposed to science, metaphysics has an inherently different approach. It can be likened to fundamental ontology.

After the Turn, Heidegger's view on the relation between philosophy and science changes. Philosophy has ended, and what should replace it can be termed as thinking. The questions asked by thinking are more fundamental than the ones asked by metaphysics. The calculating approach of science (Betrachtung) is to be replaced by Besinnung that will enable the advent of the purpose of Being. Science thus stands in opposition to thinking, which is to replace metaphysics and philosophy.

Even though on the level of metaphilosophy, as well as his approach to metaphysics, Heidegger's approach to the reflection of science before and after the Turn, there is a significant degree of the continuity of his approach present. This continuity lies predominantly in three areas - a) critical, though not negating, approach to science is maintained, even though, after the Turn, it is more elevated; b) regarding the nature of science as mathematical in the sense of it being calculating, known beforehand; c) the criticism of materializing a being by science. Thus, despite the differences in increasing the degree of criticism of science after the Turn, such as the reduction of nature to a calculable state of supply and energy, a different understanding of the relationship between science and philosophy, there is considerable continuity in Heidegger's view of science before and after the Turn. 


\section{CONCLUSION}

This paper aims to answer the question to what extent can Heidegger's approach to science before and after the Turn be considered continual and compatible. Heidegger had already remarked on science in his main texts before the Turn. His approach to science before the Turn can be considered critical. He had criticized science for materializing a being, which tears a being from context and prevents it from being known in its totality. This materialization means the reduction of a being. Heidegger regards the nature of science as mathematical in the sense that science introduces a being as knowable beforehand. He analyses the expression of time in science, and at the same time, he reveals in them a strong metaphysical longing. Here, Heidegger talks about structuring the subject of each science according to the regional structure of Being. Scientific research has its own terminology and is delineated by borders. These borders reside in the mathematical nature of science. He considers points in time and space with respect to the Cartesian coordinate system, used in science, as interchangeable. In the context of individual sciences, Heidegger also sees the fundamental understanding of basic terminology as important. In this period, he likewise considers the approach to metaphysics, dealing with the purpose of being, as a counterbalance to the partial scientific approach. Traditional ontology is to be replaced by fundamental ontology.

After the Turn, Heidegger's approach to science changes in two aspects. The first change is that his words become more critical. After philosophy was dissolved in sciences and, as Heidegger says, replaced by thinking, a second change occurred, which was the end of the dialogue between philosophy and science. After the Turn, Heidegger associates science with technology. He claims that a combination of science and technology is something we cannot come to terms with. He also speaks of the encounter of humans with global technology, claiming their academic unity is becoming more and more formal. After the Turn, he also criticizes publishers for influencing science. The operative nature of science has negative connotations in his work. Heidegger radicalizes his criticism of science. He emphasizes that humans perceive Being as a source of energy. Gestell stands behind people's predatory approach to Being. Calculation is related to the mathematical nature of science. There is also the phenomenon of the devouring of a being. Objectification of a being means putting a being into a position where it satisfies our curiosity exclusively in a way we want to know it.

There is no fundamental change in our philosopher's relationship to the sciences that would fundamentally change his attitude. His measure of criticism is increasing critical arguments from before the Turn are amended by the reduction of a being to a storage of energy and the claim that, in the original sense of the word, science does not think. What changes is also his opinion on what will balance the actions of science as a counterweight that strives for the knowledge of Being. While before the Turn, it was metaphysics, after the Turn, it is thinking whose goal is the truth of Being. What is common for both periods is Heidegger's critical approach, as well as his conviction 
of the mathematical nature of science, that science materialized a being, thus preventing grasping it in its entirety. Traditional ontology in the period before the Turn resides in favor of metaphysics. Throughout the whole of Heidegger's life, he remained convinced of science's mathematical nature, meaning the distribution of its object of research beforehand, before experience. Although Heidegger was quite critical to sciences all his professional life, he never dared to derogate their results. Perhaps a critical approach to further research in this field will help confirm the above assertions or refute them as groundless.

Acknowledgment: This paper was supported by institutional grant IG-KSV-01/202012-33/IP Interdisciplinary solutions for the study of selected aspects of social relations in the context of today's phenomena.

\section{REFERENCES}

Badger, Lee M. 2017. Phenomenology as the original science of life in Heidegger's early Freiburg lectures. Journal of the British Society for Phenomenology 48(1), 28-43. DOI: 10.1080/00071773.2016.1242664. Accessed: April 5, 2021.

Bagni, Giorgio T. 2010. Mathematics and positive sciences: A reflection following Heidegger. Educational Studies in Mathematics 73(1), 75-85. DOI:10.1007/s10649-009-9214-0. Accessed: April 5, 2021.

Batovanja, Vesna. 2009. Heidegger and the Science. Synthesis Philosophica 23(2), 401-411.

Belousov, Alexej, I. 2014. Filosofia matematiky M. Chajdeggera. Dokazatel'stvo. Očevidnost', dostovernost' i ubeditel'nost' v matematike: Trudy Moskovskogo seminara po filosofii matematiky. Moskva: Librokom, pp. 121-137.

Beran, Ondřej. 2010. Náš jazyk, můj svět.1st ed. Praha: Filosofia.

Binnetti, María J.; Králik, Roman; Tkáčová, Hedwiga and Marie Roubalová. 2021. Same and other: from Plato to Kierkegaard. A reading of a metaphysical thesis in an existential key. Journal of Education Culture and Society 12 (1), 5-13.

Caputo, John D. 1986. Heidegger's philosophy of sciences: The two essences of science. Rationality, relativism, and the human science. Dordrecht: Martinus Nijhoff, pp. 43-62.

Corti, Agustín. 2006. Zeitproblematik bei Martin Heidegger und Augustinus. 1st ed. Würzburg: Königshausen und Neumann.

De Lara, Francisco. 2014. Originary science or science of origin? A discussion of Heidegger's philosophy in his lecture courses from 1919 to 1921 . Revista de Humanidades 30, 55-75.

Dreyfus, Hubert L. 2018. How Heidegger defends the possibility of a correspondence theory of truth with respect to the entities of natural science. Heidegger Reexamined 2, Abingdon: Taylor and Francis, pp. 219-230.

Forman, Paul. 2007. The primacy of science in modernity, of technology in postmodernity, and of ideology in the history of technology. History and Technology 23(1-2), 1-152. DOI: 10.1080/07341510601092191. Accessed: April 5, 2021. 
Garcia Martin, José; Rojas Morales, Arturo and Roman Kralik. 2021. The Kantian ethical perspective seen from the existential philosophy of Søren Kierkegaard's Victor Eremita. Ethics \& Bioethics (in Central Europe) 11 (1-2) 48-57. Accessed: March 6, 2021.

Grygar, Filip. 2021. An Existential Role of Preunderstandings in the Leading Founders of Quantum Theory. Theory of Science 43(1) doi.org/10.46938/tv.2021.497. 5993. Accessed: April 5, 2021.

Heidegger, Martin. 2008. Modern science, metaphysics, and mathematics. Edited by David Krell. Basic Writings. London: Harper Collins, pp. 267-306.

Heidegger, Martin. 1977a. The question concerning technology. In Heidegger, Martin: The question concerning technology, and other essays. New York: Harper \& Row. pp. 3-35.

Heidegger, Martin. 1976. What is called thinking. 2nd ed. New York: Harper Perennial.

Heidegger, Martin. 2010. Being and time. 2nd ed. New York: State University of New York Press.

Heidegger, Martin. 1997. Phenomenological interpretation of Kant's Critique of Pure Reason. 1st ed. Indiana: Indiana University Press.

Heidegger, Martin. 1998a. Phenomenology and Theology. Edited by William McNeil, William. Pathmarks, Cambridge: Cambridge University Press. pp. 3962.

Heidegger, Martin. 1998b. What is metaphysics? Edited by William McNeil. Pathmarks, Cambridge: Cambridge University Press. pp. 82-96.

Heidegger, Martin. 1995. Aristotle metaphysics (theta) 1-3: on the essence and actuality of force. 1st ed. Indiana: Indiana Press.

Heidegger, Martin. 1977b. The age of world picture. In Heidegger, Martin: The question concerning technology, and other essays. New York: Harper \& Row. pp. 115-154.

Heidegger, Martin. 1959. An introduction to metaphysics. 1st ed. Yale University Press.

Heidegger, Martin. 1977c. Science and reflection. In Heidegger, Martin: The question concerning technology, and other essays. New York: Harper \& Row. pp. $155-182$.

Heidegger, Martin. 1998c. Postscript to "What is Metaphysics?”'Edited by William McNeil. Pathmarks, Cambridge: Cambridge University Press. pp. 231-238.

Heidegger, Martin. 1978. Letter on humanism. In Heidegger, Martin; Basic Writings. London, Routledge, pp. 193-242.

Heidegger, Martin. 1972. The end of philosophy and the task of thinking. In On Time and Being. Chicago: Chicago University Press. pp. 55-69.

Heidegger, Martin. 1981. Only a God can save us. In Heidegger: The man and the thinker. Chicago: Precedent Publishing, pp. 45-67.

Heidegger, Martin. 1971. An Interview (1969). In Listening 6, pp. 34-40.

Johnson, Edmundo F. 2012. Philosophy and science from Heidegger's early thought. Trans/Form/Acao 35(2), 121-141. 
Karaba, Miroslav. 2012. Laudan's reticulational model of scientific progress. Filosoficky casopis 60(4), 519-535.

Ke, Xiaogang. 2016. Reason and Besinnung: Heidegger's Reflections on Science in Contributions to Philosophy. Frontiers of Philosophy in China 11(3), 430-443. DOI: 10.3868/s030-005-016-0031-5. Accessed: April 5, 2021.

Köchler, Hans. 2011. The Relation Between Man and World. Analecta Husserliana 107, Astronomy and Civilization in the New Enlightenment - Passions of the Skies, Dordrecht/Heidelberg/London/New York: Springer, pp. 37-46.

Králik, Roman. 2019. Decision-making gap either/or in the life of a man. European Journal of Science and Theology 15(5), 1-2. Accessed: April 5, 2021.

Kružíková, Jana. 2010. Heideggerovo pojetí védy. 1st ed. Praha: Togga.

Kružíková, Jana. 2014. Dvojí pojětí času v Heideggerove přednášce "Der Zeitbegriff in der Geschichtwissenschaft" (1915). Heidegger v dialogu. Nové perspektivy interpretace myšlení Martina Heideggera, Praha: Togga, pp. 29-40.

Kružíková, Jana. 2016. "Basic Concepts" "Objectivisation" and "Mathematisation" The Milestones in Heidegger's Conception of Science. Filosofický časopis 64(3), 349-365.

Kuneš, Jan. 2011. Novověká matematizace, Heidegger a Kant. Spor o matematizaci světa. Červený Kostelec: Mervart, pp. 211-242.

Kvasz, Ladislav. 2006. Heidegger's account of the rise of mathematical natural science in confrontation with Husserl's conception of mathematisation in "Krisis." Filosoficky casopis 54 (2), 183-205.

Kvasz, Ladislav. 2013. Zrod vedy ako lingvistická udalost'. Galileo, Descartes a Newton ako tvorcovia jazyka fyziky. 1st. ed. Praha: Filozofia.

Leško, Vladimír. 2006. Heidegger: Modern mathematical natural science and metaphysic. Filozofia 61(5), 347-358.

Lewis, Clay. 2017. The way of nature: History \& truth in Heidegger's late thought. Cosmos and History 13(1), 73-93.

Ma, Lin and Jaap van Brakel. 2014. Heidegger's thinking on the "Same" of science and technology. Continental Philosophy Review 47(1), 19-43. DOI: 10.1007/s11007-014-9287-z. Accessed: April 5, 2021.

Mabaquiao, Napoleon, M. 2009. Heidegger's constitution and critique of science: a review. Philosophia (Philippines) 38(1), 85-104.

Mascaró, Luciano. 2017. Heidegger and the notion of truth in the ontic sciences: A rebuilding of the meanings of truth that reign over the sciences of the intraworldly. Daimon 70, 165-180. DOI: 10.6018/daimon/230681. Accessed: April 5, 2021.

Mitterpach, Klement and Štúr, Martin. 2017. Heidegger's science. European Journal of Science and Theology 13(2), 147-159. Accessed: April 5, 2021.

Moore, Ian A. 2019. Science, thinking, and the nothing as such: On the newly discovered original version of Heidegger's "what is metaphysics?" Review of Metaphysics 72(3), 529-562.

Nemec, Rastislav. 2018. Od lineárneho čítania k nelineárnemu kódu Metamorfózy obrazu v digitálnej ére. In: Miroslav Karaba, Rastislav Nemec: Človek medzi prírodou, kultúrou a technikou. Vybrané reflexie problému l'udskej prirodzenosti. Trnava: Dobrá kniha. 59-90. 
Nitsche, Martin. 2005. Starost o užívání řeči. Schizma filosofie 20. století. Praha: Filosofia, pp. 217-228.

Novák, Aleš. 2010. Heidegger's interpretation of the mathéma-character of the science. Theory of Science 32(1), 19-35.

Novosád, František. 1995. Pozvanie k Heideggerovi. $1^{\text {st }}$. ed. Bratislava: Archa, p. 171.

Paić, Žarko. 2014. The Riddle of an upcoming event: Between faith and technoscience (Heidegger - Deleuze). Bogoslovska Smotra 84(2), 195-219.

Pandiaraj, Deepak. 2019. Responding to ontological communication in the anthropocene epoch. Journal of Indian Council of Philosophical Research 36(3), 387-404. DOI: 10.1007/s40961-019-00179-1. Accessed: April 5, 2021.

Pomeroy, Anne F. 2008. Remythologizing Heidegger: Capitalism, time and authenticity. Philosophia (Philippines) 37(2), 119-138.

Rheinberger, Hans J. 2016. Heidegger and Cassirer on the sciences after the encounter in Davos. Deutsche Zeitschrift fur Philosophie 64(4), 655-666. DOI: 10.1515/dzph-2016-0047.

Rouse, Joseph. 1985. Heidegger's later philosophy of science. The Southern Journal of Philosophy 23(1), pp. 75-92. DOI: 10.1111/j.2041-6962.1985.tb00378.x.

Shaw, Robert. 2013. The implications for science education of Heidegger's philosophy of science. Educational Philosophy and Theory 45(5), 546-570. DOI: 10.1111/j.1469-5812.2011.00836.x. Accessed: April 5, 2021.

Slomski, Wojciech. 2017. Prologomena do filozofii wspolczesnej. Warszawa: Europejskie Kolegium Edukacji w Warszawie, p. 500.

Sousedík, Prokop. 2005. Carnapův pokus o kritiku Heideggerovy metafyziky. Dva protipóly evropské filosofie 20. století. Schizma filosofie 20. století. Praha: Filosofia, 195-216.

Stojka, Robert. 2015. Heidegger's Turning in the context of the relationship of man and being. Studia Philosophica 62 (1), 41-52.

Sucharek, Pavol. 2013. An artist - Pontifex oppositorum. Filozofia 68(9), 729-740.

Tholt, Pavol. 2003. J. Patočka a vznik matematickej prírodovedy. $1^{\text {st }}$ ed. Košice: Interart.

Tomašovičová, Jana. 2002. The challenge of technology - Only for Martin Heidegger?. Filozofia 57(5), 335-341.

Valčo, Michal. 2018. Global and local challenges of the interaction of natural and human sciences. European Journal of Science and Theology 14(5), 1-3. Accessed: April 5, 2021.

Vaňková, Ingrida. 2017. Život ako Story - Ja ako text: naratívne perspektívy v skúmaní osobnej identity človeka. $1^{\text {st }}$ ed. Prešov: Prešovská univerzita. p. 93.

Wolf, Thomas. 2003. Heidegger's constitution and critique of science. Zeitschrift fur Philosophische Forschung 57(1), 94-110.

Zaborowski, Holger. Věda, technika a zamyšlení nad “neužitečným”. Heidegger v dialogu. Nové perspektivy interpretace myšlení Martina Heideggera, Praha: Togga, pp. 41-68. 